\title{
PENEGAKAN HUKUM ATAS HAK KEKAYAAN INTELEKTUAL STUDI KASUS PELANGGARAN DESAIN INDUSTRI
}

\author{
JEMIRAN, SH.,MH ${ }^{\mathbf{1}}$ \\ Jemiran06@gmail.com
}

\begin{abstract}
ABSTRAK
Keberadaan Desain industri berada pada norma karya cipta dan paten, sehingga kedudukanya berada diantara kedua peraturan hukum yang mengatur hak cipta dan paten, sedangkan Desain Industri sendiri lebih menekankan pada nilai estetika dan konfigurasi bentuk dari sebuah produk industri, dan dalam perkembanganya masyarakat pengrajin mengidentikasn sebagai budaya atau halhal yang biasa, bentuk kreatifitas dan inovasi untuk mengimpelemtasikan dan mengekspresikan kemampuanya, sehingga dengan demikian hasil karyanya tidak didaftarkan ke lembaga HKI oleh para pendesainer, hal ini terikat karena sebagai pekerja atau karena hal-hal lain daripada sifat publikasi pendaftaran Desain Industri itu sendiri.

Penelitian ini merupakan penelitian Yuridis Normatif dengan menggunakan pendekatan doctrina. Penelitian hukum doktrinal yaitu penelitian-penelitian atas hukum yang dikonsepkan dan dikembangkan atas dasar ketentuan hukum posistif. Berdasarkan pada ketentuan hukum dalam produk peraturan perundang-undangan yang diberlakukan untuk mengkaji kebijakan pemenuhan hak-hak dan kewajiban pekerja atau pengrajin dalam membuat produk desain industri tersebut, akhirnya dapat ditemukan problem solving yang diharapkan.

Berdasarkan hasil analisis data, disimpulkan bahwa kedudukan Desain Industri yang dilindungi HKI terikat pada hak kebendaan immateril dan terdapat driot de suite ( royalty), baik langsung maupun tidak langsung terhadap monopoli market melalui pemberian lisensi, dan franchese, kemudian peredaran desain industri selama kurun waktu 10 ( sepuluh ) tahun, dan apabila terjadi sengketa atas pengakuan HKI dapat diselesaikan oleh para pihak dengan pilihan hukumnya ( choice of law). Dalam Penegakan hukum atas pelanggaran Desain Industri penyidik harus lebih teliti dan berhati-hati, dimana Undang-Undang Nomor 31 tahun 2001 tentang Desain Industri memeberikan pilihan hukum ( choise of law ) dalam penyelesaian sengketa apabila terjadi pelanggaran
\end{abstract}

\section{Kata kunci : Hak Kekayaan Intelektual, Desain Industri}

\footnotetext{
${ }^{1}$ Dosen Fakultas Hukum Universitas Majalengka
} 
PRESUMPTION of LAW

Fakultas Hukum Universitas Majalengka

Volume 2 Nomor 2 Oktober 2020

\section{A. Latar Belakang}

Desain Industri bagian dari ruang lingkup hak kekayaan Intelektual yang dibangun masyarakat menjadi sebuah kebutuhan masyarakat pengrajin, dan dalam perkembanganya Desain Industri merupakan hak cipta dari sesorang dalam berntuk kerangka atau pola ${ }^{2}$, yang dapat menghasilkan suatu produk, berupa barang, komoditas industri atau kerajinan tangan, hal ini juga merupakan unsur yang harus ada dalam paten, unsur seni dan estestis desain industri mengandung keindahan atau estetika yang merupakan hasil kreasi atau kreatifitas manusia sebagai karya intelektual yang dilindungi property rights.

Desain Industri yang dimilki oleh pemegang Desain Industri atau pendesain dirumuskan sebagai hak eksklusif dan dapat mengizinkan kepada pihak lain untuk menikmati manfaat ekonomi dari desain industri tersebut dengan cara lisensi sebagai perjanjian pemberian hak, bukan pengalihan hak, dimana pengalihan hak dapat diartikan beralihnya hak moral ( moral rights), pemegang hak desain industri memilki hak khusus yang tidak dapat dialihkan dalam keadaan bagaimanapun, melalui pendekatan filosofis desain industri merupakan bagian hak kekayaan intelektual ${ }^{3}$, di negara-negara Eropa memandang bahwa desain industri sebagai karya cipta,rasa dan karsa (budaya ), melalui pendekatan hak paten di negara-negara Jepang dan Amerika Serikat, desain industri dipandang sebagai produk yang bernilai bisnis, sehingga perbedaan cara pandang terhadap desain industri tersebut menyebabkan perbedaan dalam susunan normatif peraturan perundang-undangan di berbagai negara di dunia, kemudian Desain Industri ditinjau dari perspektif hak cipta, merupakan hasil dimana pemikiran atau perasaan diekspresikan dengan cara kreatif yang diwujudkan dalam bentuk karya yang bernilai estestis, sedangkan ditinjau dari perspektif paten, desain industri dapat dilihat sebagai upaya untuk mendorong terciptanya penemuan dengan mengedepankan aspek perlindungan dan kegunaanya, serta memberikan kontribusi bagi kemajuan industri, sehingga dapat dipastikan bahwa perlindungan desain industri merupakan gabungan dari perlindungan terhadap hak cipta dan paten, namun demikian desain industri tetap memilki perbedaan, desain industri lebih menekankan pada materi yang melahirkan kesan estetik, dengan mengutamakan rasa, dan efek estestikanya, selanjutnya tujuan perlindungan hukum desain industri adalah terhadap kegunaanya yaitu untuk mendorong terciptanya suatu karya desaindesain yang mengedepankan unsur perlindungan dan kegunaanya, dan dapat sebagai kontribusi bagi kemajuan perkembangan industri

Perlindungan Hak Kekayaan Intelektual; selain dilindungi berdasarkan undang-undang dalam negeri masing-masing, juga secara internasional perlindungan atas desain industri termaktub dalam :

2 Ibnu Artadi, Diskresi Polisi dan Realitas Penegakan hukum ( Studi tentang penanganan kasus kriminal tertentu versi keadilan Polisi ), Deepuublish, group penerbitan cv Budi Utama, Yogjakarta, 2013,hlm. 259.

${ }^{3}$ Ahmad M. Ramli, Cyber Law dan HAKI, Dalam Sistem Hukum Di Indonesia, PT.Refika Aditama, Bandung, 2006, hlm. 1-2. 
PRESUMPTION of LAW

Fakultas Hukum Universitas Majalengka

Volume 2 Nomor 2 Oktober 2020

1. The Paris Convention for the Protection of Industrial Property of 1883

2. The Haque Agreement Concerning the International Deposit Of Industrial Designs of 1925.

3. The Locarno Agreement Establishing an International Classification

4. TRIPs Agreement under the Worrld Trade Organization Agreement.

5. The Berne Convention for the Protection of Literary and Artistic Works of 1886

6. The Universal Copyright Convention of 1952.

7. London Act 1934 dan Haque Act 1960

Khususnya Indonesia hanya tunduk pada konvensi London Act 1934

Globalisasi membawa dampak Negara-negara di Dunia dalam membangun ekonomi Negara secara Nasional berupaya melakukan perlindungan Hak Cipta ( property rights ) bangsanya melalui meratifikasi TRIPs, dengan memperbaiki sistem politik ekonomi negera-negara di dunia, termasuk Negara Indonesia dengan sistem politik yang bebas aktif, berusaha melakukan hubungan dan komunikasi dengan negara di dunia dalam rangka menstabilkan ekonomi rakyatnya secara Nasional, melalui hubungan diplomatik, bilateral dan mengikuti perjanjian- perjanjian dibidang ,sosial ekonomi, sosial budaya, sosial politik, semua itu tidak lepas dari sistem hukum yang berlaku dimasing-masing negara di dunia.

Dalam perkembanganya perlindungan HKI, tidak lagi menjadi urusan satu negara saja, tetapi sudah menjadi urusan masyarakat Internasional, sejak ditandatanganinya Agreement Establishing the World Trade Organization (WTO), perlindungan HKI secara Internasional semakin ketat dalam Penegakan hukumnya, untuk itu dalam menyelesaikan pelanggaran di bidang HKI dapat dilaksanakan melalui badan yang bernaung di dalam sistem WTO yaitu Badan Penyelesaian Sengketa ( Dispute Settlement Body/DSB), hal ini dilakukan dalam rangka atau upaya untuk mewujudkan Perlindungan HKI secara efisien, efektif dan menguntungkan semua anggota WTO, dengan adanya kerjasama antara anggota WTO baik yang bersifat regional maupun Internasional untuk membawa perubahan ekonomi negara-negara di dunia, hal ini guna menghindari dan dapat menimbulkan terjadinya Globalisasi ekonomi sepihak, dan atau terbentuknya blok-blok perdagangan yang baru, dengan berdirinya WTO, NAFTA dan AFTA ditambah China tentunya akan berpengaruh terhadap sistem hukum negara-negara di dunia termasuk Indonesia, globalisasi sebagai pasar bebas daripada perdagangan,

Hukum sebagai landasan peraturan dibuatnya sebuah perjanjian atau kesepakatan internasional, hal ini tentunya akan mempengaruhi budaya tradisi hukum negara di dunia, seperti yang tercantum dalam kesepakatan Internasional General Agreement Tarrif and Trade ( GATT ) yang berkaitan dengan Penanaman Modal, Hak Milik Intelektual, dan jasa,. Negara Indonesia sebagai anggota WTO mau tidak mau wajib dan harus meratifikasi hukum untuk memenuhi ketentuan-ketentuan sebagaimana terdapat dalam kesepakatan 
PRESUMPTION of LAW

Fakultas Hukum Universitas Majalengka

Volume 2 Nomor 2 Oktober 2020

General Agreement Tarrif and Trade ( GATT ), Agreement on Trade Related Investment Measures ( TRIM'S ) dan Agreement on Trade Related Apects of Intellectual Property Right ( TRIP'S ), walaupun dalam menerbitkan beberapa produk peraturan perundang-undangan nantinya akan berdampak serta mempengaruhi nilai - nilai budaya bangsa Indonesia dan mungkin belum sesuai dengan kondisi dan jiwa bangsa Indonesia, namun demikian dalam perkembangan hukum jangan sampai menimbulkan timbulnya penjajahan model baru yang dapat merugikan masyarakat kecil.

Desain Industri diatur dalam Hak Kekayaan Intelektual yang dihubungkan langsung dengan perwujudan visual dari produk-produk komersial dalam pola tiga atau dua dimensi, dan dalam prakteknya Desain Industri tidak melindungi fungsi dari suatu produk, melainkan semata-mata melindungi penampakan luarnya saja, dimana produk Desain Industri suatu saat menjadi milik publik yang akan menjalankan fungsinya dalam kehidupan sosial masyarakatnya,

Produk-produk Desain Industri yang orisinil akan menjadi komersil setelah dilindunngi dan didaftarkan kepada Pemerintah melalui Menkumham, ( HKI ) dalam jangka waktu 6 ( enam ) bulan dari sejak tanggal pedaftaran/penerimaan dianggap sudah diumumkan. Kemudian dalam penegakan hokum terhadap tindak pidana yang terjadi harus memperhatikan kedudukan dan keberadaan hukumnya jangan sampai Ambiguitas Law atau Undang-undang yang didalam judisialnya tidak jelas, hal ini akan berpengaruh dan berdampak pada hambatan dalam pendeteksian penuntutan, karena kurang profesional dan karena tingginya pelanggaran kegiatan bisnis terhadap kejahatan, maka model penegakan hukum harus ekstra hati - hati dimana undang - undang secara judicial yang mengaturnya sendiri telah memberikan batasan-batasan spesifikasinya atau kekhususanya, baik dalam menentukan suatu perbuatan melawan hukum maupun sanksi atas kejahatan yang dilanggar, dan atau berupa Administrasi yang bersifat sementara, Pasal 103 KUHPidana memberikan batasan normatif terhadap pelangaran yang terjadi

Dalam kerangka teori hukum pananggulangan kejahatan hukum pidana, menurut G.P. Hoefnagels menyatakan upaya penanggulangan kejahatan dapat ditempuh dengan upaya-upaya :

1. Penerapan hukum pidana ( Criminal law application )

2. Pencegahan tanpa pidana (Prevention withaut punishment)

3. Mempengaruhi pandangan masyarakat mengenai kejahatan dan pemindanaan lewat mas media (influencing views of society on crime and punisment/mas media) ${ }^{4}$.

Selanjutnya dalam kibijakanya peradilan pidana harus mempertimbangkan sebab-sebab struktural, termasuk sebab-sebab ketidakadilan yang bersifat sosioekonomi, dimana kejahatan sering hanya

${ }^{4}$ Barda Nawawi Arief, Kibajakan Hukum Pidana, Perkembangan penyusunan konsep KUHP baru, Kencana Predana Group, Jakarta, 2011,hlm. 45. 
PRESUMPTION of LAW

Fakultas Hukum Universitas Majalengka

Volume 2 Nomor 2 Oktober 2020

merupakan gejala/symptom ( policies for crem prevention and criminal justice should take into account the stuctural causes, including socio-economic causes of injustice, of which criminality is often but a symtom ) ${ }^{5}$. Friedman berpendapat bahwa dalam sistem hukum merupakan satu keseluruhan yang terdiri dari komponen - komponen :

1. Substantif ( norma/kaidah,azas hukum )

2. Structure ( struktur hukum )

3. Culture ( budaya hukum $)^{6}$

bahwa sistem tidak lagi dipandang sebagai sesuatu yang statis, akan tetapi ditelaah sebagai sesuatu yang dinamis, hidup, tumbuh dan berkembang dalam konteks sosial masyarakat, untuk itu paradigma hukum dapat dipandang sebagai sesuatu yang dinamis pula, dalam arti hidup, tumbuh dan berkembang, sejalan dengan perkembangan peradaban manusia yang dipicu oleh perkembangan ilmu pengetahuan dan teknologi dan dalam konteks tersebut, pemahaman terhadap hukum tidak sekedar sebagai suatu " rumusan hitam putih "(blue print) yang ditetapkan dalam berbagai bentuk peraturan perundang-undangan, Hukum hendaknya dilihat sebagai suatu gejala yang dapat diamati di dalam masyarakat melalui tingkah laku warga masyarakatnya, kemudian hukum juga harus dipandang sebagai suatu sistem nilai yang secara keseluruhan didasarkan pada sebuah norma dasar ( grundnorm atau basic norm ) sebagai penuntun dalam penegakan hukumnya, serta grundnorm juga merupakan sumber nilai sebagai pembatas dalam penerapan hukum, Hans Keelsen memandang grundnorm sebagai the basic norm as the source of identity and as the source of unity of legal system? ${ }^{7}$.

Produk-produk Desain Industri yang memilki nilai ekonomis, suatu saat akan menjadi milik publik dan menjalankan fungsinya sebagai suatu kebutuhan kehidupan sosial masyarakat, dengan demikian akan menimbulkan adanya keterikatan pada perkembangan beberapa masalah atau kondisi sosial yang dapat merupakan faktor penyebab timbuln kondusifnya suatu kejahatan, faktor-faktor tersebut merupakan masalah yang tidak dapat diatasi dengan "“ penal ", akan tetapi menunjukan adanya keterbatasan dalam penal, untuk itu harus ditunjang oleh jalur " non penal ",. untuk mengatasi masalah - masalah yang dilatar belakangi daripada kebijakan publik yang telah menjadi kebijakan sosial, guna mengatasi pelanggaran atau masalah tersebut penegakanya dilakukan melalui pencegahan tanpa pidana ( prevention withaout punishment ) .

Desain industri merupakan bagian hak atas kepemilikan Intelektual ( Intellectual property right), dan juga sebagai kepemilikan hak atas suatu benda yang sah, ditinjau dari perspektif hukum benda dapat diwujudkan melalui karya cipta sebagai kekayaan/ kreasi intelektual., dan juga dapat beralih atau dialihkan serta dapat dipertahankan kepemilikanya kepada siapa

${ }^{5}$ Ibid hlm 48

6 Esmi warassih, Pranata Hukum sebuah telaah Sosiologis,, Penerbit Universitas Dipenegoro 2011, hlm 21 .

${ }^{7}$ Ibid hlm 70. 
PRESUMPTION of LAW

Fakultas Hukum Universitas Majalengka

Volume 2 Nomor 2 Oktober 2020

pun. Benda dalam kerangka hukum perdata diklasifikasikan sebagai benda berwujud dan benda tidak berwujud, "( Pasal 503 KUHPerdata kebendaan ialah, tiap-tiap barang dan tiap-tiap hak, yang dapat dikuasai oleh hak milik.") dalam rumusan judicial ini ditafsirkan bahwa hak milik adalah benda sebagai obyek hak milik, yang terdiri dari " barang" dan "hak". Selanjutnya " Barang siapa memperoleh kedudukannya atas suatu kebendaan dengan kekerasan, tidak diperbolehkan menuntut kembali biaya- biaya yang dikeluarkannya, kemudian kebendaan dalam proses perniagaan dapat diklasifikasi sebagai perbuatan hukum, yaitu sebagai :

1. Pemberian kuasa/Lastgeving sebagai suatu perjanjian yang di situ seseorang memberikan kuasa kepada seorang lain, dan orang ini menerimanya untuk atas namanya, menyelenggrakan suatu urusan,

2. sebagai kepentingan "Jika seorang dengan sukarela, dengan tidak mendapat perintah untuk itu atau tanpa mendapat pesanan untuk itu, mewakili urusan orang lain dengan atau tanpa pengetahuan orang ini, maka ia secara diam-diam mengikat dirinya untuk meneruskan serta menyelesaikan urusan tersebut, hingga orang yang diwakili kepentinganya dapat mengerjakan sendiri urusan itu,

3. sebagai kenyataan hukum, "Suatu perikatan dengan suatu syarat taguh adalah suatu perikatan yang bergantung pada suatu peristiwa yang masih akan datang dan yang masih belum tentu akan terjadi, atau yang bergantung pada suatu hal yang sudah terjadi tetapi tidak diketahui oleh kedua belah pihak,

Dengan melihat hal tersebut diatas, maka akan memungkinkan berpengaruhnya pola-pola interaksi sosial terhadap para penegak hukum, baik pola-pola positif atau negatif dalam pergaulan hidup sehari-hari, kemungkinan para penegak hukum akan mengalami keadaan dimana berhadapan dengan pola interaksi sosial negatif, keadaan yang terpaksa ( force majeur) dan memungkinkan kapan terjadi keadaan terpaksa atau keadaan darurat sebagai hasil dari Kebijaksanaan ( beleid ), para penegak hukum berusaha untuk menghasilkan pola-pola interaksi sosial tertentu yang akhirnya melembaga dalam masyarakat, hal itu akan terjadi sangat tergantung pada derajat efektifitas dari hukum yang diterapkan dalam masyarakat.

Sebagai Perbandingan kasus Desain Industri yang terjadi perkara pelanggaran/kejahatan yang dilaporkan ke penyidik Polri sebagai delic aduan, dengan Laporan polisi Nomor : 13-13/B/I/20014/Reskrim, tanggal 08 Januari 2014, atas nama Pelapor .SINDU HANDOYO Bin KASTURI. selaku pemegang hak eksklusif Desain Industri, sebagai barang bukti sertifikat desain industri yang dikeluarkan oleh Kementrian Hukum dan Ham RI, Direktur Jendral HKI masing-masing sebanyak 4 ( empat ) lembar sertikat Desain Industri, nomor . ID.0 031 378-D dan 4 (empat ) lembar sertifikat Desain Industri atas nama KIM SOO CHANG warga negara Korea Selatan dengan nomor pendaftaran ID 0031 480-D tanggal 30 juli 2012 dengan pelkau Sdr. PARK CHAE YOUNG warga negara Korea Selatan dan SOEMADYO Bin SOETARYO selaku pemegang otorisasi CV SIN SIL RATTAN alamat Desa 
PRESUMPTION of LAW

Fakultas Hukum Universitas Majalengka

Volume 2 Nomor 2 Oktober 2020

Penajalin Kidul Kecamatan .Sumberjaya Kabupaten .majalengka, dengan tuduhan telah melakukan penjualan dan eksport barang jenis Nampan FOC Dekor dan FOC Lis tanpa seijin dari pemilik Desain Industri ( pelapor ) sebagaimana dimaksud dalam Pasal (9). UU 31 tahun 2000 tentang Desain Industri, Proses penyidikan yang dilakukan penyidik polri kasusnya dalam tahap P-19 dengan catatan Jaksa Penuntut Umum memerintahkan agar penyidik melengkapi keterangan saksi ahli, baik dari kalangan akademisi maupun dari Departemen Hukum dan Ham. ( HKI ).

Dengan permasalahan Desain Industri yang berkembang dikalangan masyarakat tertentu ( pengrajin ) dan perbandingan kasus pelanggaran desain industri yang terjadi, menarik untuk disimak sebagai kajian terhadap keseimbangan ( equilibrium ) dan harmonisasi hukum dengan memberikan para pihak kesempatan dan keterlibatan korban untuk berperan dalam proses penyelesaian tindak pidana dengan mengedepankan keadilan restoratif., dimana hukum pidana umum lebih mementingkan kepentingan umum atau masyarakat luas atau negara, dengan menekankan dan menunjukan melalui sifat memaksanya.

\section{B Identifikasi Masalah}

Berdasarkan latar belakang diatas dapat diketahui bahwa Desain Industri adalah bagian dari Hak Atas Kekayaan Intelektual yang memiliki nilai kebendaan, untuk itu penulis tertarik untuk melakukan penelitian mengenai :

1. Bagaimanakah penegakan hukum atas pelanggaran Desain Industri

2. Bagaimanakah langkah penyidik di dalam mengimplementasikan penegakan hukum atas pelanggaran Desain Industri

\section{Tujuan Penelitian}

Sesuai dengan permasalahan di atas, maka tujuan penelitian ini adalah:

1. Untuk mengetahui dan menganalisa penegakan hukum atas pelanggaran Desain Industri.

2. Untuk mengatahui langkah penyidik didalam penegakan hukum atas pelanggaran desain industri yang seharusnya dilakukan

\section{Kerangka Pemikiran}

Dilihat dari keadaan masyarakat Indonesia yang bersifat paternarlistik yang menggantungkan pada pola " client - patron relationship ", memandang hukum sebagai perlindungan kepentingan manusia sebagai individu yang dibatasi oleh kepentingan-kepentingan kolektif semua anggota masyarakat dan nilai baik dari sudut pandang masyarakatnya, berbeda dengan hukum barat yang menitik beratkan pada manusia sebagai individu yang memberikan kebebasan seluas-luasnya untuk melindungi kepentingan dirinya, dan dalam proses litigasi memilki karakteristik kepastian hukum dalam mencapai 
PRESUMPTION of LAW

Fakultas Hukum Universitas Majalengka

Volume 2 Nomor 2 Oktober 2020

keadilan $^{8}$,walaupun telah ada perubahan litigasi ke arah nonlitigasi melalui intrumen hukum itu dapat dipandang juga sebagai alternatif penyelesaian sengketa, hal ini semata-mata untuk mempertahankan ketertiban dan kedamaian dalam kehidupan masyarakat,.

Sistem hukum Negara Indonesia yang dibentuk bersumber pada Pancasila sebagai filsafat hidup bangsa Indonesia, hal ini memerlukan pandangan baru tentang hukum, dimana hukum bukan hanya sebagai sistem norma dan logika ( norms dan logic ) dan sistem perilaku dan juga sistem nilai ( values system ), akan tetapi juga harus dipandang sebagai satu kesatuan, dan merupakan jati diri dari sistem hukum Indonesia. Jika hal itu dilandaskan pada proposisi hukum sebagai sistem norma yang mengutamakan norms and logic, tidak berhasil diwujudkan dalam sistem perilaku dan birokrasi yang sama-sama taat kepada hukum, maka akan kehilangan arti dan makna dalam kenyataan kehidupan masyarakat, begitu juga sebaliknya apabila hukum dipandang hanya sebagai sistem norma dan perilaku saja akan berdampak hukum hanya sebagai mesin birokrasi dan akan kehilangan rohnya jika mengabaikan sistem nilai yang bersumber pada Pancasila sebagai puncak nilai kesusilaan dalam kehidupan berbangsa dan bernegara.

Proposisi tersebut sebagai teori hukum Integratif yang disebut Tripartite Character of the legal theory of social and Bureucratic Enginnering , kemudian penetapan Indonesia sebagai negara hukum merupakan perspektif resmi yang utama dalam politik hukum nasional yang memberikan tuntutan agar hukum dapat berperan aktif atau menjadi sentral dalam kehidupan bermasyarakat, untuk itu, Desain Industri sebagai karya cipta seseorang bangsa Indoensia secara tidak langsung turut serta membangun perekonomian nasional Negara melalui sistem ekonomi kreatif masyarakat modern, dalam pekerjaan Desain Industri oleh warga masyarakat pengrajin sebagai kerajinan tangan.

Negara melalui instrumen pemerintah yang bekerjasma dengan lembaga legislatif harus mampu melindungi serta melakukan pengawasan terhadap perkembangan Desaian Industri, dimana dalam perjalanan dapat menimbulkan sengketa atau masalah yang dihadapkan pada sebuah kejahatan, maka diperlukan sebuah kebijakan hukum dan penegakannya, kebijakan formulatif legislatif sebaagai kebijakan dalam tahap penegakan hukum pidana in abstraco oleh badan pembentuk undang-undang untuk menetapkan atau merumuskan perbuatan apa yang dapat dipidana yang berorientasi pada permasalah pokok dalam hukum pidana meliputi perbuatan yang bersifat melawan hukum, kesalahan atau pertanggungjawaban pidana dan sanksi apa yang dapat dikenakan terhadap pelaku dimana Desain merupakan hasil karya cipta seseorang dalam bentuk pola atau kerangka, yang kemudian dikerjakan dengan melibatkan orang lain sehingga membentuk sebuah produk, dari hasil produknya dapat dijadikan komoditas industri yang siap dipasarkan dan dapat

${ }^{8}$ Adami Chazawi, Pelajaran Hukum Pidana Bagian I, Raja Grafindo Persada, Jakarta, 2001, hlm. 156. 
PRESUMPTION of LAW

Fakultas Hukum Universitas Majalengka

Volume 2 Nomor 2 Oktober 2020

menimbulkan penyalahgunaan atau penggunaan Desain Industri tanpa seizin pemiliknya, kebijakan atau upaya penanggulangan pada hakikatnya merupakan bagian integral dari upaya perlindungan masyarakat ( social defence ) dan upaya mencapai kesejahteraan masyarakat ( social welfare), untuk itu kejahatan tidak dipandang sebagai "masalah hukum" semata, tetapi sebagai masalah sosial, penanggulangan kejahatan bukan semata-mata urusan para penegak hukum ( kepolisian, kejaksaan, pengadilan ), tetapi sebagai masalah/ urusan dalam negeri yang melibatkan berbagai departemen, penanggulangan kejahatan dilakukan secara integral dengan lebih difokuskan pada upaya preventif / kausatif yaitu dengan menanggulangi sebab dan kondisi Desain karya cipta seseorang dalam bentuk pola, kerangka sebagai dasar para pengrajin untuk mengerjakan sebuah pekerjaan yang disesuaikan dengan pola dan kerangka tersebut sehingga membentuk sebuah produk industri memiliki nilai dan berharga telah dilindungi oleh undang-undang.

Desain Industri merupakan suatu kreasi tentang bentuk, konfigurasi, atau komposisi garis atau warna, atau garis dan warna, atau gabungan daripadanya yang berbentuk tiga dimensi atau dua dimensi yang memberikan kesan estetis dan dapat diwujudkan dalam pola tiga dimensi atau dua dimensi serta dapat dipakai untuk menghasilkan suatu produk, barang, komoditas. industri, atau kerajinan tangan, untuk memajukan industri yang mampu bersaing dalam lingkup perdagangan nasional dan internasional perlu diciptakan iklim yang mendorong kreasi dan inovasi masyarakat di bidang Desain Industri sebagai bagian dari sistem hak kekayaan intelektual, untuk itu pemerintah dalam melakukam perlindungan hukum terhdap hak Desain Industri, lebih mengedepankan pada proses mediasi karena hal itu berkaitan dengan dunia bisnis yang didalam setiap perbuatanya dapat diklasifikasikan pada perbuatan sumir yang perlu dipertegas dengan unsur-unsur pidananya, yaitu dapat dan tidaknya si pembuat mempertanggungjawabkan pidananya didalam proses penyelesaian pelanggaran sebagai karya kreasi Desain yang diciptkannya.

\section{E Metode Penelitian}

Penelitian ini merupakan penelitian Yuridis Normatif dengan menggunakan pendekatan doctrina. Penelitian hukum doktrinal yaitu penelitian-penelitian atas hukum yang dikonsepkan dan dikembangkan atas dasar ketentuan hukum posistif. Berdasarkan pada ketentuan hukum dalam produk peraturan perundang-undangan yang diberlakukan untuk mengkaji kebijakan pemenuhan hak-hak dan kewajiban pekerja atau pengrajin dalam membuat produk desain industri tersebut, akhirnya dapat ditemukan problem solving yang diharapkan.

Pendekatan yuridis merupakan pendekatan terhadap masalah-masalah yang diteliti dengan menghubungkan hukum dari masalah tersebut, dengan melalakukan identifikasi pada Undang-Undang No 31 tahun 2000 tentang Desain Industri, terhadap teori-teori pemindanaan dalam penegakan hukum pidana maupun diluar hukum pidana, selanjutnya mengkaji penerapan- 
PRESUMPTION of LAW

Fakultas Hukum Universitas Majalengka

Volume 2 Nomor 2 Oktober 2020

penerapan hukum dan pendapat para ahli yang terkait dari aspek praktis dan aspek akademis keilmuan hukumnya.

Bahan hukum yang digunakan dalam penelitian ini disesuaikan adalah:

1. Bahan hukum primer yaitu Bahan hukum primer merupakan bahan hukum yang terdapat dalam suatu aturan hukum yang memiliki otoritas sebagai teks otoritatifnya, seperti Undang-Undang Desain Industri.

2. Bahan hukum sekunder merupakan bahan hukum yang diperoleh dari bukubuku teks, jurnal-jurnal, pendapat para ahli hukum, kasus-kasus hukum serta simposium yang dilakukan para pakar hukum,..

\section{F. Hasil Penelitian dan Pembahasan}

\section{Penegakan Hukum Atas Pelanggaran Desain Industri}

Desain Industri dalam masyarakat pengrajin sebagai budaya, secara Subtansi hukum yang dibangun masyarakat pengrajin adalah norma kepercayaan ( trust ), sehingga Desain industri dapat diklasifikasikan sebagai bagian budaya dalam kelompoknya dan dalam perkembanganya Desain Industri di pandang sebagai sesuatu hal yang biasa serta sebagai kebiasaan dalam mengekspresikan suatu kreatif dan inovasi dalam komunitasnya, bahkan apabila hasil karyanya di tiru, digunakan, dan dipublikasikan oleh orang lain pemilik desain merasa bangga dan berbesar hati bahwa karya ciptanya beredar di masyaraakat, dalam peredaranya terukur pada nilai kepercayaan ( trust), dan terhadap pemahaman royalty Desain Industri sendiri yang merupakan bagian dari hak atas Kekayaan Intelektual yang terlindungi hak eksklusif kurang mendapatkan tempat sebagai sesuatu yang harus dilakukan proteksi oleh para pengrajin

Kedudukan desain industri diapresiasikan sebagai budaya Intelektualitas seseorang, melalui berpikir secara logika serta mengolah akal menjadi pengetahuan yang diterima oleh panca indra akan diwujudkan untuk mencapai suatu kebenaran, kemudian melalui ingatan dan khayalan itu membentuk sebuah imajinasi untuk menghasilkan suatu kenyataan sebagai penggerak sikap inisiatif. manusia dalam berekspresi dan berinovasi untuk berbuat atau tidak berbuat sesuatu, dari hasil kreatifitas tersebut diimplementasikan sebagai karya cipta, inovasi intelektualitas dan menghasilkan pola atau kerangka yang dirumuskan sebagai karya cipta desain industri dan bermanfaat bagi kelompok pengrajin guna pembentukan konfigurasi bentuk daripada barang komoditas industri

Desain Industri merupakan Hak Kekayaan Intelektual yang memiliki hak kebendaan yang berupa benda immateril atau benda yang tidak berwujud yang dirumuskan sebagai hak intelektualitas ( intellectual property rights ), dan dalam perkembanganya tidak semua orang dapat memperkerjakan otaknya secara maksimal, untuk itu hanya orang yang mampu memperkerjakan otaknya secara maksimal yang dapat menghasilkan

9 Soerjono Soekanto \& Sri Mamudji, Penelitian Hukum Normatif, suatu tinjauan Singkat, jakarta, Raja Grafindo Persada 2007 hlm 24 
PRESUMPTION of LAW

Fakultas Hukum Universitas Majalengka

Volume 2 Nomor 2 Oktober 2020

sebuah karya cipta desain industri, oleh karenanya secara administrasi Pemerintah melalui lembaga Hak Kekayaan Intelektual (HKI) melindungi atas karya cipta tersebut

Dari hasil penelitian dan wawancara dengan sumber ditemukan bahwa perkembangan desain industri di kalangan masyarakat khususnya masyarakat pengrajin di hadapkan pada dua jenis masalah yakni kelompok yang bergerak dibidang sub kontraktor yaitu masyarakat perkerja sebagai penerima Surat Perintah Kerja (SPK) dari perusahaan yang memiliki pola atau kerangka desain industri, Perusahaan yang menciptakan pola desain industri menjadi barang komoditas industri atau produksinya serta menjalankan marketing sendiri, antara lain sebagai berikut :

a) Desain Industri pada sub kontraktor sebagai buruh atau pengrajin

1). Desain industri dapat diperoleh karena adanya perintah dari salah satu perusahan pemilik pola atau kerangka desain industri yang diterima untuk dikerjakan menjadi sebuah produk atau barang komoditas industri,

2). Perolehan pola desain industri diperoleh melalui jasa internat antara ketua kelompok pengrajin dengan owner yang dikirim langsung melalui email, berupa gambar, pola atau kerangka bentuk, konfigurasi, dimensi warna daripada desain industri.

3).CV Make alamat Desa Leuwilaja Kecamatan Sindangwangi Kabupaten Majalengka dalam hal ini sebagai sub kontraktor penerima pekerjaan atas desain industri tersebuat yang terdiri dari para kelompok pekerja atau buruh untuk melakukan suatu pekerjaan, selanjutnya CV Make dengan para buruh terikat pada perburuhan dan menimbulkan perikatan baik sebagai pekerja pada CV Make juga berkaitan upah kerja sebagai hak atas hasil perkejaannya, dan juga secara tidak langsung terikat langsung dengan perusahaan atau owner pemilik pola atau kerangka desain industri tersebut.

4). CV Make sebagai sub kontraktor dalam pekerjaanya terikat pada kontrak pekerjaan dengan perusahaan atau owner yang memberi pekerjaan itu, secara in cloude CV Make diberi hak penuh atau kuasa penuh untuk menyelesaikan pola desain industri menjadi barang komoditas industri atau sebagai hasil produksi, baik dari mempersiapkan bahan baku sampai upah kerja para buruh serta kontrol kualitas barang.

5). Dalam menjalankan pekerjaan kedudukan para pihak tidak dibuat secara tertulis, melainkan melalui kepercayaan ( trust ), kemudian dalam penegakan hukum apabila terjadi pelangaran atas kesepakatan tersebut akan diselesaikan melalui mediasi, namun demikian dalam hal azas pembuktian hukum sebagai proses penegakan hukum yang dibuat secara tertulis melalui sebuah perjanjian kontrak pekerjaan menjadi resiko para pihak sebagai konsekuensi kepercayaan ( trust ) para pihak.

b) Desain Industri pada pemegang otoritas hak Eksklusif. 
PRESUMPTION of LAW

Fakultas Hukum Universitas Majalengka

Volume 2 Nomor 2 Oktober 2020

1).PT Ravindo yang beralamat di jalan Pangeran Muhamad Desa Buahkapas Kecamatan Sindangwangi Kabupaten Majalengka merupakan perusahaan yang bergerak dibidang industri rotan.

2). Dari mulai pembuatan pola atau Kerangka desain industri, bahan baku industri sampai pekerjaan Produksi rotan yang dikerjakan merupakan hasil desain indiustri sendiri, baik dari penyiapan bahan baku rotan sampai proses pekerjaanya, dikerjakan bersama dengan sub-sub kotraktor selaku pengrajin atau buruh yang ada dibawahnya.

3). CV Ravindo dalam marketnya melakukan hubungan dagang dengan berbagai distributor atau bayer dalam memasarkan / marketing daripada hasil produkasinya, baik di dalam negeri maupun di manca negara di dunia, diantaranya PT L.O.D dari Inggris, PT M.D.M dari Perancis dan PT G.C.I dari Belanda.

4). CV Ravindo selama ini telah memproduksi industri rotan sebagai karya ciptanya sampai sekarang telah memproduksi mencapai kurang lebih 500 item atau jenis, dalam berbagai bentuk dan konfigurasi desain industri, serta membangun hubungan kelompok pengrajin sebanyak 26 sub kotraktor yang tersebar di beberapa wilayah kabupaten majalengka dan Cirebon.

5). Semua produk yang dihasilkan merupakan milik perusahaan CV Ravindo sebagai konfigurasi bentuki desain industri menjadi barang komoditas industri, serta menentukan hubungan dagang dengan berbagai distributor atau bayer baik didalam negeri maupun ke luar negeri.

6). Setiap produk hasil CV Ravindo diberi label sebagai ciri produksi CV Ravindo, mulai nama jenis barang, kegunaanya, dan kode produksi contoh kode produksinya HILFARTHER KORBHAUS Item RVD 06001 RC, Description ARTHUR BABY ROCKING CHAIR. W/3 cm H. SEAT CUSHION C-0O2 Batch, Material 1 KOOBOO GREY/ NAT UNFIN MAHOOGANY / COLONIAL.

7). Semua produk CV Ravindo yang diberi label merupakan milik sah perusahaan baik pada tataran hak Desain Industri, hak merek dan Paten secara eksklusif dapat memonopoli market atau pasar dan dapat dijual kepada siapa saja, kecuali ada persetujuan lain dengan pihak bayer atau pemeberian lisensi hak eksklusif yang melekat pada barang produksi dapat diberikan kepada distributor atau bayer, kemudian pihak CV Ravindo sendiri secara langsung maupun tidak langsung tidak dapat menjual jenis barang tersebut, apabila karena hak eksklusif telah dipindah tangankan kepada bayer yang ditunjuk dalam daerah atau negara tertentu dimana distributor atau bayer berada.

8). Dari semua persetujuan pengalihan lisensi hak eksklusif para pihak tidak dibuat secara perjanjian kontrak tertulis, namun berdasarkan kepercayaan ( trust ), PT L.O.D dari Inggris diantaranya yang telah menerima pengalihan hak eksklusif dari CV Ravindo sebanyak 250 item dengan berbagai jenis barang desain industri. 
PRESUMPTION of LAW

Fakultas Hukum Universitas Majalengka

Volume 2 Nomor 2 Oktober 2020

9). Produk-produk yang diproduksi CV Ravindo telah mencapai 500 item, namun secara umum produk - produk sebagai hasil karya cipta CV Ravindo tidak didaftarkan ke lembaga HKI, dalam pengawasan atas pelanggaran produk-produk dipasaran oleh pihak lain atau orang lain dilakukan dengan cara menual atau kepercayaan ( trust) pasar.

Dalam perkembangan penegakan hukum Desain Industri kedudukanya berada pada hukum perdata, hukum pidana dan hukum administrasi HKI, dan perbuatanya secara khusus dimasukan pada tindak pidana khusus baik pada azas legalitas maupun unsur-unsur delic desain industri dapat dikualifikasikan sebagai delic khusus, maka didalam penegakan hukumnya atas pelanggaran Desain Industri perlu diciptakan peraturan hukum yang dapat mengakomodir keberadaan perkembangan Desain Industri di masyarakat, sebagai referensi Pasal 1365 KUHPerdata sebagai suatu pertanggungajawaban perbuatan melawan hokum bahwa " Tiap perbuatan melanggar hukum, yang membawa kerugian kepada seorang lain, mewajibkan orang yang karena salahnya menerbirkan kerugian itu, mengganti kerugian itu “, walaupun dalam rumusan ini membawa banyak kalangan orang untuk menafsirkan terhadap pengertian perbuatan melawan hukum yang menginginkan adanya perbaikan dalam arti dari perbuatan melawan hukum itu sendiri.

Didalam dinamika perkembangan hukum yang dinamis, perbuatan melawan hukum banyak dipengaruhi oleh sistem hukum negara-negara di dunia baik penganut sistem anglo saxon maupun Eropa Kontinental, Negara Indonesia sendiri dalam mengaplikasikan perbuatan melawan hukum dapat diekpresikan sebagai perbuatan yang mengandung unsur-unsur antara lain :

a) Unsur perbuatan yang melawan hukum dalam arti yang luas.

b) Unsur adanya kesalahan.

c) Unsur adanya kerugian yang ditimbulkan

d) Unsur hubungan klausal antara perbuatan dan kerugian.

Kemudian unsur kesalahan dapat diukur secara obyektif dimana unsur kesalahanya harus dapat dibuktikan bahwa kesalahan itu dilakukan oleh manusia yang normal, selanjutnya secara subyektif bahwa unsur kesalahanya itu dapat diteliti sebagai kesalahan yang diduga si pembuat sebagai perbuatan berdasarkan keahlian yang dimilikinya, kemudian dalam penegakan hukum atas pelanggaran Desain Industri didasarkan pada hukum positif, yaitu Undang-Undang Nomor 31 tahun 2000 tentang Desain Industri, namun demikian hukum pada hakikatnya mengandung ide atau konsep-konsep yang abstrak, sekalipun abstrak, tapi ia dibuat untuk diimplemntasikan dalam kehidupan sosial sehari-hari dalam masyarakat, oleh karenanya perlu adanya kegiatan untuk mewujudkan ide-ide tersebut ke dalam masyarakat, rangkaian kegiatan tersebut dalam rangka mewujudkan ide-ide tersebut menjadi kenyataan.. Penegakan hukum hendaknya tidak dilihat sebagai suatu yang berdiri sendiri, melainkan selalu berada di antara berbagai faktor ( interchange), serta dalam pemahaman terhadap hukum 
PRESUMPTION of LAW

Fakultas Hukum Universitas Majalengka

Volume 2 Nomor 2 Oktober 2020

juga tidak sekedar sebagai suatu " rumusan hitam putih " ( blue print) yang ditetapkan dalam berbagai bentuk peraturan perundang-undangan, akan tetapi hukum dapat dilihat sebagai suatu gejala yang dapat diamati didalam masyarakat melalui tingkah laku warga masyarakatnya, baik yang berhubungan antara hukum dengan faktor-faktor non hukum lainya sebagai budaya hukumnya atau kultur hukum yang dibangun untuk membuat adanya perbedaan dalam penegakan hukum, antara masyarakat yang satu dengan masyarakat lainya.

Dalam penegakan hukum pelanggaran desain Industri berada pada dua peraturan hukum yaitu :

a) Hak Cipta sebagai undang-undang yang mengatur dan menempatkan tindak pidana sebagai delik biasa, sebalumnya hak cipta dikategorikan sebagai kualifikasi delic aduan, perubahan sifat delic ini adalah merupakan kesepakatan masyarakat yang menyebabkan suatu pelanggaran bisa diperkarakan ke pengadilan secara cepat dan tidak perlu menunggu pengaduan terlebih dahulu dari pemegang hak cipta.

b) Hak Paten sebagai bagian hak kekayaan intelektual yang di kategori hak kekayaan perindustrian ( industrial property right ), sebagaiman hak kekayaan intelektual itu sendiri adalah bagian dari kebendaan baik benda yang tidak berwujud ( immateril ), maupun tidak berwujud, secara yuridis segala sesuatu yang dapat menjadi objek hak adalah benda yang berwujud, akan tetapi dapat menjadi objek hak itu tidak hanya benda berwujud, akan tetapi benda yang tidak berwujud juga dapat dijadikan objek hak, yaitu Paten merupakan suatu hak khusus berdasarkan undangundang diberikan kepada si pendapat / si penemu ( uitvinder ), atau menurut hukum pihak - pihak yang berhak memperolehnya atas permintaanya yang diajukan kepada pihak penguasa, baik temuan baru dibidang teknologi maupun perbaikan atas temuan yang sudah ada, cara kerja baru, atau menemukan suatu perbaikan baru dalam cara kerja, untuk selama waktu tertentu yang dapat diterapkan dalam bidang industri.

Sifat perlindungan desain industri mendekati kesamaan dengan perlindungan Paten, sebab hanya inventor yang menghasilkan invensi saja yang dapat diberikan hak, baik dikerjakan invensinya sendiri maupun memberi persetujuan kepada pihak lain untuk melaksanakannya., dan yang dimaksudkan invensi disini adalah berupa ide yang lahir dari penemuan tersebut, bukan hasil dalam bentuk produk materil atau bendanya, melainkan idenya yang kemudian membuahkan hasil dalam bentuk benda materil, dimana ide ini dapat diklasifikasikan sebagai benda immateril yang lahir dari proses intelektualitas manusia

Delic terhadap pelanggaran paten termasuk dalam delic aduan, dengan pertimbangan bahwa hal ini menjadi sulit memberi batasan tentang tidak digunakan untuk kepentingan komersil, hal demikian semakin sulit pemegang paten untuk mengajukan tuntutan pidana, karena pengadu harus 
PRESUMPTION of LAW

Fakultas Hukum Universitas Majalengka

Volume 2 Nomor 2 Oktober 2020

yakin terlebih dahulu bahwa hal itu benar-benar merugikan kepentingan yang wajar

Dalam analisis hukum pidana formil sistem hukum pidana Indonesia yang merujuk pada Kitab Undang-undang Hukum Acara Pidana ( KUHAP ) sebagai lege generali, berlaku terhadap semua jenis perkara pidana pada semua tingkat pemeriksaan. kemudian sejak tahun 1960 KUHAP telah disampingkan sebagai lege generali oleh ketentuan khusus hukum acara untuk beberapa jenis perkara pidana tertentu, selanjutnya keberadaan hukum acara pidana khusus merupakan konsekunsi logis dari keberadaan hukum pidana khusus pada ketentuan Pasal 103 KUHPidana.

Penyimpangan dan kekhususanya dalam hukum materiel berdaampak terhadap hukum formil undang-undang tersebut yang secara normatif dan ekplisit menyimpang dari ketentuan hukum acara pidana umum.

Dalam konteks ini terdapat dua penyimpangan atas azas-azas umum dalam fungsi hukum pidana konvensional.

a) Fungsi hukum pidana bersifat ultimum remedium atau the lost resort ( mencapai ketertiban dan kepastian hukum guna menemukan keadilan ) dengan menentukan :

1). Korban karena kejahatan sangat besar.

2). Terdakwa residivis

3). Kerugian korban tidak dapat dipulihkan.

b) Metode pembuktian ( proof beyond reasonable doubt) mernggunakan mteode pembuktian terbalik murni yaitu antara pelaku kejahatan dan korban kejahatan atau pihak yang bersengketa dapat melakakukan pilihan hukum ( choice of law ) dalam menyelesaikan sengketanya.

Desain Industri keberadaanya berada pada dua peraturan hukum yaitu peraturan perundang-undangan hak cipta dan paten keduanya menghimpit kedudukan pendesain apakah sebagai pecipta atau sebagai penggagas dan atau idenya dalam proses pembuatan desain Indsutri menjadi barang komoditas produk industri, dengan persepsi inilah para pendesainer jarang mendaftarkan karya ciptanya kepada HKI dengan pertimbangan keberadaanya dan kedudukanya desain industri berada pada lingkup hak cipta dan paten, selanjutnya berkaitan dengan tuntutan pidana atas pelanggaran yang ditimbulkan adalah delic aduan, hal ini perlu menjadi perhatian dan kajian secara khusus kepada para penyidik, dimana dalam pembuktian terhadap kualifikasi delic desain indsutri yang ditimbulkan perlu extra hati - hati serta untuk tidak tergesa-gesa meningkatkan penyelidikan menjadi penyidikan..mengingat adanya kesepempatan para pihak untuk melakukan rekopensi atas peristiwa hukum yang mengakibatkan hukum pada pelanggaran desain industri.

\section{Langkah Penyidik Dalam Mengimplementasikan Penegakan Hukum Atas Pelanggaran Desain Industri}

Sebagai perbandingan Peristiwa hukum perkara atau kasus pelanggaran Desain Industri yang terjadi, kemudian dilaporkan ke penyidik 
PRESUMPTION of LAW

Fakultas Hukum Universitas Majalengka

Volume 2 Nomor 2 Oktober 2020

Polri sebagai delic aduan, Laporan polisi Nomor : 1313/B/I/20014/Reskrim, tanggal 08 Januari 2014, pelapor Sdr SINDU HANDOYO Bin KASTURI bertindak selaku dan atas nama pemegang hak eksklusif Desain Industri sebanyak 4 ( empat ) lembar sertikat Desain Industri, sebagaimana surat pendaftaran dan sertifikat desain industri yang dikeluarkan oleh Kementrian Hukum dan Ham RI, Direktur Jendral HKI Nomor : ID.0 031 378-D dan 4 ( empat ) lembar sertifikat Desain Industri atas nama KIM SOO CHANG warga negara Korea Selatan dengan nomor pendaftaran ID 0031 480-D yang daftarkan tanggal 30 juli 2012, dengan terlapor Sdr. PARK CHAE YOUNG warga negara Korea Selatan dan SOEMADYO Bin SOETARYO selaku dan atas nama CV SIN SIL RATTAN Ds Penajalin Kidul Kec.Sumberjaya Kab.majalengka, dengan tuduhan telah melakukan penjualan dan eksport barang jenis Nampan FOC Dekor dan FOC Lis tanpa seijin dari pemilik Desain Industri ( pelapor) dan statusnya ditingkatkan menjadi tersangka dengan tuduhan sebagaimana dimaksud dalam Pasal 9 Undang-Undang Nomor 31 tahun 2000 tentang Desain Industri.

Melalui orientasi Pasal 103 KUHPidana yang memberikan ketentuan perbuatan yang diatur diluar KUHP, hal ini sebagai pilihan hukum ( choice of law ) kepada para pihak yang bersengketa dalam Desain Industri, kemudian Undang-undang No.31 tahun 2000 juga memberikan ketegasan para pihak untuk melakukan upaya hukum lain sebagai rekopensi atas delic yang ditimbulkan, terlapor sebagaimana laporan pengaduan, melakukan rekopensi sebagai upaya hukum melalui gugatan perdata ke Peradilan Niaga Jakarta pusat dan diperoleh keputusan Pengadilan Niaga Jakarta Pusat Nomor : 40/Pdt.Sus-DI/2014/PN.Niaga Jkt.Pst. tanggal 23 September 2014 , yang memutuskan " tidak terbukti adanya penyimpangan bukti yang berkaitan dengan pelanggaran hak desain industri. " selanjutnya pengadilan memerintahkan dalam waktu paling lama 30 hari sejak dikeluarkanya surat penetapan, pengadilan niaga yang memeriksa sengketa harus memutuskan untuk mengubah, membatalkan atau menguatkan penetapan tersebut, sehingga penyidik wajib memperhatikan sebagaimana dimaksud dalam Pasal 81 KUHPidana yang menyatakan "Penundaan penuntutan pidana berhubung dengan adanya perselisihan pro-yudisial, menunda daluwarsa",

Berangkat dari konsep rancangan KUHPidana yang bertolak pada materi subtansi yang menjadi masalah pokok dalam hukum pidana adalah :

a) masalah tindak pidana,

b) masalah kesalahan atau pertanggungjawaban pidana

c) masalah pidana dan pemidanaan ${ }^{10}$.

Dalam prinsip-prinsip hukum pidana dinyatakan bahwa tindak pidana adalah perbuatan melakukan atau tidak melalukan sesuatu yang oleh peraturan perundang-undangan dinyatakan sebagai perbuatan yang dilarang dan diancam dengan pidana, dalam Principle of legality yang menjadi

\footnotetext{
${ }^{10}$ Barda Nawawi Arief, Kebijakan Hukum Pidana, ...Loc.Cit
} 
PRESUMPTION of LAW

Fakultas Hukum Universitas Majalengka

Volume 2 Nomor 2 Oktober 2020

pokok hukum pidana bahwa perbuatan yang dituduhkan harus merupakan perbuatan yang dilarang dan diancam dengan pidana oleh suatu peraturan perundang-undangan, agar perbuatan tersebut dapat dijatuhi pidana, dan perbuatan tersebut harus juga bertentangan dengan hukum, sebagaimana azas hukum Nullum delictum nulla poena sine praevia lege ( tidak ada delic, tidak ada pidana tanpa peraturan lebih dahulu ).

Dalam dinamika hukum Hak Kekayaan Intelektual sebagai tindakan kreatif dan inovatif seseorang yang dapat menghasilkan suatu benda yang memiliki hak kebendaan, adalah hak atas sesuatu benda yang bersumber dari hasil kerja otak, dengan mengedepankan rasio dan menalar, dapat menghasilkan berupa benda immateril, yang kemudian dikelompokan menjadi Hak Cipta, ( copy rights ), dan menjadi hak milik (Industrial property rights ). Pengaruh Convention Establishing The Word Intellectual Property Organization, hak milik ( industial property rights ) dapat di klasifikasikan menjadi : a) Patent ( Paten ), b) Utility Model ( Rodel dan Rancang Bangun atau simple patent), c). Industrial Design (Desain Industri ), d). Trade Merk ( Merek Dagang) dan Indication of source or Appelation of Origin ( sumber tanda atau sebutan asal ), karena pengaruh sistem hukum Anglo Saxon kekayaan Perindustrian yang berkembang perlu dilindungi dari beberapa bidang diantaranya 1). Trade secrets, 2). Service mark, 3) unfair competition, dan dalam perkembanganya kekayaan perindustrian khususnya desain industri banyak dipengaruhi berbagai hukum perikatan atau hukum kontrak yang dalam perjalananya banyak ditemukan terhadap perbuatan melawan hukum seperti wanprestasi dan itikad baik.

Perbuatan wanprestasi atau itikad baik sebagai perbuatan melawan hukum sebagai perbandingan di Negara-negara penganut sistem hukum anglo saxon ( Inggris ) memandang bahwa perbuatan melawan hukum disejajarkan dengan suatu kesalahan yang menimbulkan gugatan dari pihak yang dirugikan, meskipun kerugian itu sebatas dugaan adanya kesalahan, dan kesalahan itu dapat di ganti dengan ganti rugi terhadap kerusakan sebagai pelanggaran kontrak, berbeda dengan kesalahan yang dapat menimbulkan kriminal atau pidana akibat tindakan pelanggaran, gangguan dan kelaian,

Dalam analisis hukum pidana materiel, azas umum hukum pidana yang dianut secara universal adalah azas legalitas yang merupakan larangan berlaku restroaktif dan mencegah adanya multitafsir terhadap ketentuan undang-undang pidana serta menciptakan kepastian hukum, dimana Undang-Undang Nomor 31 tahun 2000 tentang Desain Industri merupakan tindak lanjut kesepakatan terbentuknya organisasi perdagangan Dunia ( WTO ) dan persetujuan TRIP's, sehingga perlu martifikasi Undang-Undang Nomor 7 tahun 1994 dan mengatur secara khusus ketentuan mengenai Desain Industri.guna mendukung ratifikasi Paris Convention for the protection of industrial Property ( konvensi Paris ) dan Keputusan Presiden Nomor 15 Tahun 1997 dalam keikutsertaan Indonesia dalam The Hague 
PRESUMPTION of LAW

Fakultas Hukum Universitas Majalengka

Volume 2 Nomor 2 Oktober 2020

Agreement (London Act) Concerting the International Deposit of Industrial Designs. Untuk itu perlu perlindungan hukum terhadap Desain Industri, dengan Undang-Undang yang mengatur secara khusus menjamin perlindungan hak-hak Pendesain, menetapkan hak dan kewajibanya serta menjaga agar pihak yang tidak berhak tidak menyalahgunakan hak desain Industri, serta untuk mewujudkan komitmen terhadap persetujuan TRIP's terhadap penjiplakan, pembajakan dan peniruan atas Desain Industri yang telah dikenal secara luas, kemudian metode pembuktian terhadap pelanggaran Desain Industri perlunya kerjasama internasional, perhatian terhadap karakteristik delic yang terjadi pada kejahatan bisnis di era globalisasi yang terikat pada perkembangan teknologi dan informasi, mengakibatkan mempersempit jarak baik pada tempus delicti maupun locus delicti suatu perbuatan, semakin tipis dalam hal tempus dan locus delicti akan menambah kesulitan dari aspek penegakan hukum, karena batas-batas yuridiksi suatu negara dan negara sekitarnya semakin jelas akan terjadi tumpang tindih (ambiguitas law) dan akan membawa masalah hukum terhadap konflik yuridiksi ( conflicting jurisdication ).

Kedudukan dan keberadaan kejahatan bisnis berada pada satu sisi dari satu mata uang yakni disatu sisi berada pada aspek hukum perdata disisi lain terdapat aspek hukum pidana, yang keduanya memiliki tujuan yang berbeda secara diametral baik pada sifat dan karateristiknya, hukum perdata lebih menekankan pada perdamaian diantara para pihak, sehingga sifat regulasinya lebih dominan terkait hubungan hukum antar perorangan atau kelompok dengan tujuan yang hendak dicapai memelihara keseimbangan ( harmonisasi ) antara kepentingan para pihak, sedangkan aspek hukum pidana lebih mementingkan melindungi kepentingan umum, masyarakat luas dan negara, sehingga sifat memaksa lebih ditunjukan dibandingkan dengan sifat regulasi, untuk mengatur hubungan hukum antara warga negara dengan Negara. Kemudian dalam dinamika penegakan hukum ( sifat memaksa ) ke dalam lingkup hukum perdata, sifat memaksa dalam konteks keperdataan dapat dinyatakan sebagai sebuah pengakuan, dan pengakuan disini menjadi sifat pengakuan yang mutlak dan tanpa syarat, mengakibatkan tidak ada lagi ruang netral atau abu-abu ( grey area) dan/ atau tidak ada lagi ruang tawar- menawar ( bergaining ) sehingga sesungguhnya telah terjadi kooptasi hukum pidana terhadap objek pengaturan dalam lingkup hukum perdata, lain halnya sifat pengakuan yang tidak mutlak dengan syarat masih ada pada posisi tawar menawar antara kedua pola penyelasaian masalah hukum sebagai choice of law Undang-Undang Desain Industri dapat diklasifikasikan sebagai undangundang tindak pidana khusus, dimana sebagai objek dan subjek hukumnya, atau orang atau pelakunya yang bersifat khusus, serta sifat perbuatanya juga khusus ( hijzonderlijk foiten ), sehingga ketentuan-ketentuan aturan pidana khusus tertulis sebagai peraturan atau karakteristiknya. Pelanggaran Hak Desain Industri yang bersifat Delic aduan, dirumuskan dalam UndangUndang Nomor 31 tahun 2000 antara lain: 
PRESUMPTION of LAW

Fakultas Hukum Universitas Majalengka

Volume 2 Nomor 2 Oktober 2020

a) Pasal 9 (1) Pemegang Hak Desain Industri memilki hak eksklusif untuk melaksanakan Hak Desain Industri yang dimilikinya dan untuk melarang orang lain tanpa persetujuanya membuat, memakai, menjual, mengimpor, mengekspor dan/atau mengedarkan barang yang diberi Hak Desain Industri.

b) Pasal 7 (1) Jika suatu Desain Industri dibuat dalam hubungan dinas dengan pihak lain dalam lingkungan pekerjaanya, Pemegang Hak Desain Industri adalah pihak yang untuk dan/atau dalam dinasnya desain industri itu dikerjakan, kecuali ada perjanjian lain antara kedua pihak dengan tidak mengurangi han Pendesain apabila penggunaan Desain Industri itu diperluas sampai ke luar hubungan dinas. dan ayat (2) sebagimana dimaksud dalam ayat (1) berlaku pula bagi Desain Industri yang dibuat orang lain berdasarkan pesanan yang berlaku dalam hubungan dinas. Kemudian ketentuan-ketentuan sebagaimana dimaksud dalam Pasal 7 (1) dan (2 ) tidak menghapus hak Pendesain untuk tetap dicantumkan namanya dalam Sertifikat Desain Industri, Daftar Umum Desain Industri, dan Berita Resmi desain Industri.( Pasal 8)

c) Pasal 23. Terhitung sejak Tanggal Penerimaan, seluruh pegawai Direktorat Jenderal atau orang yang karena tugasnya bekerja untuk dan.atau atas nama Direktorat Jenderal berkewajiban menjaga kerahasiaan permohonan sampai dengan diumumkannya permohonan yang bersangkutan

d) Pasal 32. Pengalihan Hak Desain Industri tidak menghilangkan hak Pendesain untuk dicantumkan nama dan identitasnya, baik dalam Sertifikat Desain Industri, Berita Resmi Desain Industri, maupun dalam Daftar Umum desain Industri.

Keadilan restoratif merupakan pergeseran paradigma dalam sistem hukum yang berkembang sebagai regulasi penegakan hukum pidana, bahwa suatu perbuatan pidana menitik beratkan pada nilai konflik atau kerusakan yang timbul akibat tindak pidana, dan dapat dipandang sebagai konflik yang terjadi dalam hubungan antara anggota masyaraakat yang harus diselesaikan dan dipulihkan oleh seluruh pihak secara bersama-sama, dengan penyelesaianya berpusat pada keseimbangan ( equilibrium ), untuk memberikan kesempatan terhadap korban untuk berperan dalam proses penyelesaian tindak pidana, kemudian Polri sebagai penyelengara Negara dan pemerintahan berdasarkan Undang-Undang Nomor 2 tahun 2002 tentang Kepolisian Negara Republik Indonesia Pasal 16 (1 ) mnyatakan : “ Dalam rangka menyelenggarakan tugas sebagaimana dimaksud dalam Pasal 13 dan 14 di bidang proses pidana, Polri berwenang untuk mengadakan tindakan lain menurut hukum yang bertanggung jawab." Tindakan lain tersebut adalah tindakan penyelidikan dan penyidikan yang dilaksanakan jika memenuhi syarat sebagai berikut :

a) Tidak bertentangan dengan suatu aturan hukum. 
PRESUMPTION of LAW

Fakultas Hukum Universitas Majalengka

Volume 2 Nomor 2 Oktober 2020

b) Selaras dengan kewajiban hukum yang mengharuskan tindakan tersebut dilakukan.

c) Harus patut, masuk akal, dan termasuk dalam lingkunganjabatanya.

d) Menghormati hak azasi manusia.

Ketentuan lain yang serupa dapat dijumpai di dalam Pasal 7 (1) huruf ( $\mathrm{j}$ ) Undang-undang Nomor 8 tahun 1981 tentang KUHAP yang menyatakan bahwa " Penyidik sebgaimana dimaksud dalam Pasal 6 (1) huruf ( a), karena kewajibanya mempunyai kewenangan mengadakan tindakan lain menurut hukum yang bertanggungjawab, diskresi polisi yang ditegaskan dan ditetapkan dalam Pasal 18 (1) huruf ( I ) UU Nomor 2 tahun 2002 menyatakan " Untuk kepentingan umum pejabat Kepolisian Republik Indonesia dalam melaksanakan tugas dan wewenangnya dapat bertindak menurut penilaiannya sendiri.

Dalam mengimpelemntasikan penegakan hukum dikeluarkanya Peraturan Kepolisian Negara Republik Indonesia Nomor 14 tahun 2012 tentang Manajemen Penyidikan Tindak Pidana sebagai tindakan positif serta proses impelemntasi terhadap penegakan hukum, Pasal 2 peraturan tersebut menegaskan :

a) Sebagai pedoman dalam penyelenggaraan manajemen penyidikan tindak pidana di lingkungan Polri.

b) Terselenggaranya manajemen penyidikan yang meliputi perencanaan, pengorganisasian, pelaksanaan, pengawasan dan pengendalian secara efektif dan efesien.

c) Sebagai evaluasi penilaian kinerja penyidik dalam proses penyidikan tindak pidana guna terwujudnya tertib administrasi penyidikan dari kepastian hukum.

Pasal ( 4 ) huruf (c) tentang laporan hasil penyelidikan junto Pasal 11 ayat (1), (2) dan (3), ayat (1) adalah :

a) kegiatan penyelidikan dilakukan sebelum ada laporan polisi/pengaduan

b) sesudah ada laporan polisi/pengaduan atau dalam rangka penyidikan, ayat (2) kegiatan penyelidikan sebagaimana dimaksud pada ayat (1) huruf $\mathrm{b}$ dilakukan untuk mencari dan menemukan tindak pidana.ayat (3) kegiatan penyelidikan sebagaimana dimaksud pada ayat 1 huruf (b) merupakan atau salah satu cara dalam melakukan penyidikan untuk :

1). Menentukan suatu peristiwa yang terjadi merupakan tindak pidana atau bukan.

2). Membuat terang suatu perkara sampai dengan menentukan pelakunya dan

3). Dijadikan sebagai dasar melakukan upaya paksa.

Penyelidik sebagaimana dimaksud dalam Pasal 13 diwajibkan :

(1) Petugas penyelidik dalam melaksanakan tugas penyelidikan, wajib melengkapi dengan surat perintah penyelidikan yang ditandatangani oleh atasan penyelidik selaku penyidik. 
PRESUMPTION of LAW

Fakultas Hukum Universitas Majalengka

Volume 2 Nomor 2 Oktober 2020

(2) Petugas penyelidik wajib membuat laporan hasil penyelidikan kepada pejabat pemberi perintah.

(3) Laporan hasil penyelidikan sebagaimana dimaksud pada ayat (2) disampaikan secara tertulis, atau lisan yang ditindaklanjuti dengan laporan secara tertulis paling lambat 2 X 24 (dua kali dua puluh) jam

Peraturan Kabareskrim Polri ( PERKABA ) sebagai Standar Operasional Prosedur ( SOP ) mempertegas terhadap :

a) Peraturan kabareskrim Polri Nomor 1 tahun 2014 tentang Standar Operasional Presedur Perencanaan Penyidikan Tindak Pidana.

b) Peraturan kabareskrim Polri Nomor 2 tahun 2014 tentang Standar Operasional Presedur Pengorganisasian Penyidikan Tindak Pidana.

c) Peraturan kabareskrim Polri Nomor 3 tahun 2014 tentang Standar Operasional Presedur Pelaksanaan Penyidikan Tindak Pidana.

d) Peraturan kabareskrim Polri Nomor 4 tahun 2014 tentang Standar Operasional Presedur Pengawasan Penyidikan Tindak Pidana.

Sebagai rekomendasai terhadap fungsi kepolisian dalam negara sebagaimana Pendapat Plato dalam ( polizeistaat ) yang artinya negara yang menyelenggarakan keamanan, kemakmuran dan perekonomian, sehingga dalam negara Polisi dikenal sebagai :

a) Sicherheit polizei yang artinya berfungsi sebagai penjaga tata tertib dan keamanan.

b) Verwaltung polizei atau wohlfart polizei yang artinya berfungsi sebagai penyelenggara perekonomian atau penyelenggara semua kebutuhan hidup warga negara.

\section{G. Kesimpulan}

1. Kedudukan Desain Industri yang dilindungi HKI terikat pada hak kebendaan immateril dan terdapat driot de suite ( royalty), baik langsung maupun tidak langsung terhadap monopoli market melalui pemberian lisensi, dan franchese, kemudian peredaran desain industri selama kurun waktu 10 ( sepuluh ) tahun, dan apabila terjadi sengketa atas pengakuan HKI dapat diselesaikan oleh para pihak dengan pilihan hukumnya ( choice of law ), hal ini ditegaskan dalam Undang-Undang Nomor 31 tahun 2000 tentang Desain Industri, penegakan hukum atas pelanggaran desain industri melaui choice of law yakni Lembaga Arbitrase (ADR ) sebagai lembaga non Litigasi dengan mengedepankan mediasi, negosisasi. Gugatan perdata melalui pengadilan Niaga dan pengaduan kepada penyidik polri atau PPNS (KUHAP), hal demikain sebagai bagian dari sistem hukum yang berkembang untuk mencari keadilan restoratif bagi para pihak terhadap pilihan hukumnya ( Choise of law ) dalam upaya yang tepat dalam penyelesaian sengketa Desian Industri.

2. Memperhatikan standar operasional prosedur Kepolisian Negara Republik Indonesia bagi para penyidik polri dapat mengimplementasikan terhadap 
apa yang menjadi ketentuan tersebut, dan juga perhatian terhadap paradigma kebijakan hukum pidana yang telah bergeser terhadap cara pandang dalam penegakan hukum perlu diimplementasikan secara nyata, untuk itu dalam kasus pelanggaran Desain Industri sebagaimana laporan Polisi No.Pol : 13-13/B/I/2014/Reskrim tanggal 8 Januari 2014, dengan objek yang menjadi sengketa adalah sertifikat HKI Desain Industri, yang telah inkrah atas putasan Pengadilan Niaga Jakarta Nomor : 40/Pdt.SusDI/2014/PN.Niaga Jkt.Pst. tanggal 23 September 2014. sebagai rekopensi atau upaya hukum atas delic yang yang diajukan pihak terlapor kepada Penagadilan Niaga, maka sepatutnya kasus tersebut penyidik dapat melakukan :

a) Surat perintah pengehentian penyidikan.

b) Surat penetapan pengenhentian penyidikan

c) Surat pemeberitahuan pengehentian penyidikan

\section{H. Saran}

Secara yuridis Normatif Undang-Undang No 31 Tahun 2000 tentang Desain Industri dapat menjadi bagian dari fungsi hukum pidana yang bersifat ultimum remedium atau the last resort yakni untuk mencapai ketertiban dan kepastian hukum guna menemukan keadilan, pengaruh globalisasi dapat beralihnya fungsi hukum pidana, namun demikian fungsi hukum akan menjadi ( primum remedium atau the prime resort) yakni untuk kepentingan ketertiban, serta kepastian hukum dan menemukan keadilan, secara filosofis perubahan fungsi hukum bahwa dalam konteks nilai-nilai kegiatan bisnis, pelaku bisnis yang beritikad baik telah ditemukan, dan menjalankan bisnis secara proposional, sehingga ketertiban dan kepastian hukum dapat berjalan guna menemukan keadilanya. 


\section{DAFTAR PUSTAKA}

\section{A. Buku :}

Adami Chazawi, Pelajaran Hukum Pidana Bagian I, Raja Grafindo Persada, Jakarta, 2001.

Ahmad M. Ramli, Cyber Law dan HAKI, Dalam Sistem Hukum Di Indonesia, PT.Refika Aditama, Bandung, 2006.

Barda Nawawi Arief, Kibajakan Hukum Pidana, Perkembangan penyusunan konsep KUHP baru, Kencana Predana Group, Jakarta, 2011.

Esmi warassih, Pranata Hukum sebuah telaah Sosiologis,, Penerbit Universitas Dipenegoro 2011.

Ibnu Artadi, Diskresi Polisi dan Realitas Penegakan hukum ( Studi tentang penanganan kasus kriminal tertentu versi keadilan Polisi ), Deepuublish, group penerbitan cv Budi Utama, Yogjakarta, 2013.

Soerjono Soekanto \& Sri Mamudji, Penelitian Hukum Normatif, suatu tinjauan Singkat, jakarta, Raja Grafindo Persada 2007.

\section{B. Peraturan Perundang-undangan}

Undang-Undang Dasar Negara Republik Indonesia Tahun 1945,

Kitab Undang-Undang Hukum Pidana (KUHP)

Kitab Undang Undang Hukum Acara Pidana (KUHAP).

Undang-Undang Nomor 31 tahun 2000 tentang Desain Industri

Undang-Undang Nomor 5 Tahun 1984 tentang Perindustrian 